\title{
Cooperation in limnology, a further achievement of the IBP
}

\section{C.M. Yonge}

The Functioning of Freshwater Ecosystems. Edited by E.D. Le Cren and R.H. Lowe-McConnell. Pp.588. (Cambridge University Press: 1980.) £40, \$95.

THE objective of the International Biological Programme was the furtherance of our understanding of the biological basis of productivity and its relation to human welfare. The study of productivity involved the organization of international studies on land, in the sea and in freshwaters. The last-named posed the greatest problems, both because previous international studies had been slight and because conditions in such waters range so very widely - from oligotrophic highland lochs to tropical alkaline lakes containing dense but specifically restricted algal populations which support equally specialized fish and bird populations.

Because it involved the stimulation of self-financing local enquiries, no section of the programme demanded greater organization. The eventual world-wide participation is indicated in the maps which adorn the end pages of this book which, following earlier publications concerned largely with methodology, represents the final outcome of the freshwater programme or, more concisely, IBP/PF. Under the overall supervision of the Director General, Dr Barton Worthington, especial responsibility rested with the fulltime coordinator, Dr Julian Rzoska, to whose dedicated activities, including the particularly close involvement of eastern European countries, this impressive volume is a tribute.

As Professor Livia Tonelli, the last of a number of convenors, writes in the Introduction, "This book is the result of years of a corporate effort by many scientists all over the world to advance the knowledge of production limnology". The truth of this statement is borne out when it is realized that it represents the combined contributions of no less than 43 authors reporting from the 93 widely scattered sites. Not only was interest so widely stimulated but important bilateral projects came into being between such widely separated countries as West Germany and Brazil, France and Chad, Japan and Malaya, and Britain and Uganda.

Freshwaters vary widely in character and consequent productivity; they are also quickly and often profoundly influenced by local human activities with consequences ranging from total toxicity to extreme eutrophication. Yet they also have great potential, realized most fully in Southeast Asia, for the production of fish and prawns for human consumption.

All means of control, alike against damage and towards increased productivity, depend on basic understanding of prevailing conditions. It is this that is the

theme of the book. The chapters range from discussion of the effects of physical and chemical variables to analysis of primary and secondary production. Studies on the significance of organic matter and decomposers are followed by chapters on trophic relationships and efficiencies, then come others dealing with estimations of productivity and consideration of the value of dynamic models of lake productivity. The final

chapter by G.G. Winberg provides a most interesting summary of the results of Soviet freshwater studies.

The overall result with its final 66 pages of references is a volume of unique value to all limnologists and one of the major achievements of the International Biological Programme.

Sir Maurice Yonge is an Honorary Fellow in Zoology at the University of Edinburgh.

\section{Wooldridge and Linton re-viewed}

\section{F. W. Shotton}

The Shaping of Southern England. Institute of British Geographers Special Publication, No 11. Edited by David K. C Jones. Pp.274. (Academic: 1980.) £14.60, $\$ 34.50$.

THIS book was commissioned by the Institute of British Geographers to celebrate the fortieth anniversary of the publication of Wooldridge and Linton's Structure, Surface and Drainage in SouthEast England (IBG, 1939). In a preface and ten chapters, eleven authors are involved, some of them more than once. This assembling of the latest opinions of geomorphologists on the evolution of the topography of their own terrain, namely the Thames Basin, the Weald and the Hampshire Basin, will be appreciated by geologists and geographers from a much wider area. The evolution of the form and drainage of this part of England was argued about long before Wooldridge and Linton, as K. Clayton points out. The value of Structure, Surface and Drainage lay less in its conclusions than in the way it combined meticulous field observation with scientific interpretation and thus steered geomorphological thought to its present position.

Although it is stated that the book is a memorial to Wooldridge and Linton, only four chapters examine their conclusions critically. Two of these, by D. K. C. Jones and R. J. Small respectively, deal with the development of the landscape during the Cainozoic era, and although Small adds the words "an alternative interpretation" to his title, it is more of an alternative to Wooldridge and Linton than to Jones. Both authors reject two of the main tenets of the original interpretation, which postulated a late Oligocene or earlyMiocene "Alpine storm" of earth deformation with subsequent tectonic quiescence while the land surface was reduced to a peneplane, and a marine invasion (the so called Calabrian or lateNeogene transgression) to a height of about $200 \mathrm{~m}$. Instead they envisage a succession of deforming pulses from the early Eocene onwards, with concurrent erosion or deposition.

Two other papers, by C. A. Baker with D. K. C. Jones and by C. P. Green and D. F. M. McGregor, deal with the diversions of the course of the Thames during the Pleistocene. These I found less satisfying, for although the authors differ from several points of the original interpretation, they also reveal how much still remains unresolved. On the age and origin of the Chiltern Drift, surely preCromerian but not inevitably a till, there is no clear consensus.

The other contributions are not so closely related to Wooldridge and Linton but are no less interesting because of that. They deal with the origin of the sarsens, the residual deposits of the North Downs, the palaeohydrology of the Kennet Valley and the effect of periglacial weathering on Chalk. A final chapter by C.P. Green describes the development of geomorphology as it is now understood and practised, and discusses its probable future. Green points out that modern geomorphology, combining as it does the study of land form and drainage, the physical processes by which these are developed, stratigraphy, sedimentology, palaeoenvironment reconstructions and relative and absolute chronology, was taken over by geographers from the geologists. It gives no pleasure to me to read (and half admit) that this was due to "the relative lack of interest in the Quaternary among British geologists". In fact Wooldridge, acknowledged as one of the great pioneers in modern geomorphology, was, by training and early employment, a geologist. Green's chapter emphasizes that geomorphology is now neither simple geography nor geology but a hybrid of both, biology also providing a formative influence. The subject is truly scientific and very much a part of earth science.

F. W. Shotton is Emeritus Professor of Geology at the University of Birmingham. 